\title{
A New Carbon Tax in Portugal: \\ A Missed Opportunity to Achieve the Triple Dividend?
}

\author{
Alfredo Marvão Pereira \\ The College of William and Mary \\ Rui M. Pereira \\ The College of William and Mary \\ Pedro G. Rodrigues \\ Universidade de Lisboa, Portuga
}

College of William and Mary

Department of Economics

Working Paper Number 161

First Version: June 2015

Revised: January 2016 
COLLEGE OF WILLIAM AND MARY

DEPARTMENT OF ECONOMICS

WORKING PAPER \# 161

January 2016

\title{
A New Carbon Tax in Portugal: A Missed Opportunity to Achieve the Triple Dividend?
}

\begin{abstract}
In 2014, the Portuguese government appointed a Commission for Environmental Tax Reform that formulated a carbon-tax proposal designed to achieve three dividends: to help Portugal meet the European Union's target for emissions reductions by 2030, to boost long-term employment and GDP above their pre-carbon-tax levels, and to strengthen public finances by lowering public indebtedness. A key feature of this proposal was a judicious set of mixed strategies to recycle all carbon-tax revenues back into the economy. In this note, we show how the carbon tax that the Portuguese Parliament eventually approved deviated from such guidelines, and ultimately failed to achieve the triple dividend. We argue that authorities need to quickly amend the existing legislation to avoid this misguided attempt turning into a missedopportunityto improve environmental, macroeconomic, and fiscal outcomes.
\end{abstract}

Keywords: Carbon Tax;TripleDividend;Economic Growth; Fiscal Consolidation;Dynamic General Equilibrium; Portugal.

JEL Classification: D58, H63, O44.

Alfredo Marvão Pereira

Department of Economics,

The College of William and Mary, Williamsburg, USA

PO Box 8795, Williamsburg, VA 23187

ampere@wm.edu

Rui M. Pereira

Department of Economics,

The College of William and Mary, Williamsburg, USA

PO Box 8795, Williamsburg, VA 23187

rmpereira@wm.edu

Pedro G. Rodrigues

CAPP, Center for Administration and Public Policies, ISCSP, School of Social and Political Sciences

Universidade de Lisboa, Portugal

R. Almerindo Lessa, 1300-663 Lisboa, Portugal

prodrigues@iscsp.ulisboa.pt 


\section{Introduction}

Portugal has pledged to cut its carbon-dioxide emissions by 2030 by $40 \%$ in relation to 1990 levels (European Commission, 2014c).Reaching this target, on time, will require a public policy that lowers the carbon intensity of the Portuguese economy, well beyond what will be achieved with the ongoing trends both in the price of fossil fuels and in domestic energy-efficiency gains.

There is a growing consensus among policy-makers - thathas long been accepted among economists- that putting a price on GHG pollution is the most effective means of reducing our carbon footprint (see, for example, Stern, 2007;Krupnick et al., 2010;OECD, 2011;Aldy and Stavins, 2012;Mankiw, 2013;IMF, 2014; and Parry et al., 2014). Indeed, carbon taxes are preferred to topdown regulations for three reasons: by 'internalizing the externality'in a less-invasive way, they encompass all possible margins of adjustment in the fight against global warming (Mankiw, 2013), they spur innovation in energy efficiency beyond the regulated targets, by diverting demand to cleaner renewable alternatives (Stern,2007; World Bank, 2014), and, importantly, they provide revenues that can be recycled back into the economy and into the environment (Jorgenson, 2014).

This 'tax and dividend' approach, whereby pollution is taxed away and the proceeds are allocated to lowering taxes aimed at spurring economic growth,thereby improving public finances, is at the heart of what is known in the literature as the second and the third dividends(see, for example, Goulder, 1995;Nordhaus, 2010; Metcalf, 2010; and Pereira and Pereira,2014a). The first dividend is of an environmental nature, and is naturally connected with the reduction in carbon-dioxide emissions. The second dividend is related to macroeconomic performance, specifically if the levels of employment and of GDP are higher with the carbon tax. The third and final dividend is connected with the budgetary position, andmaterializes with a lower ratio of public debt to GDP.

A double dividend involves simultaneously obtaining environmental and economic gains as a result of a tax on carbon (see, for example, Bovenberg, 1999; and Ligthart, 1998). Although a tax on 
carbon has a direct negative effect on GDP, the cost of significantly reducing pollution can be driven to zero, even without taking into account the resulting environmental benefits (Goulder, 1995). For that to happen, policymakers need to lower marginal tax rates at other distortionary margins so as to improve efficiency. By shifting the tax burden from physical and human capital to carbon emissions, the burden of the whole tax system is reduced,households benefit from higher incomes, and the economy's aggregate performance improves. Indeed, one of the main distortionary effects of taxation is lower levels of employment, as personal-income taxes, value-added and excise taxes, as well as social security contributions all reduce a worker's consumption wage (OECD, 2004). Nevertheless, Jorgenson et al. (2013) caution that such gains are not a foregone conclusion, and that policymakers need to make informed judgments, in particular regarding what to do with the carbontax revenues. In fact, if these are distributed lump sum back to households, then no double dividend takes place.

Since the beginning of this century, Portugal has witnessed disappointing economic growth, to the extent that it has consistently fallen behind in terms of real convergence to its EU peers. In fact, during the2000s, the Portuguese economy grew at an annual average of $0.7 \%$, or about half of the rate for the EU-28 (see European Commission, 2015a). Similarly, Portugal has been plagued by a structurally-weak budgetary position. In the wake of the global financial crisis of 2008, Portugal lost access to international bond markets in mid-2011, and only recently has Portugal exited a strict EUECB-IMF adjustment program. Indeed, between the end of 2008 and the end of 2011, reflecting the effects of the financial crisis, the public-debt-to-GDP ratio rose by nearly 40 percentage points to $111.1 \%$. Since then, despite a tight fiscal policy, it reached $130.2 \%$ by the end of 2014 (again, see European Commission, 2015a).

In such a contextof historically-high levels of public indebtedness, where fiscal space is now meagre and the economic recovery is still nascent, Portugal needs to realize the triple dividend. In 
addition to reducing carbon emissions and restoring economic growth through higher levels of employment, fiscal consolidation tops the policy agenda. As such, great care is needed in terms of the specific design of a carbon tax. It is definitely not enough for Portugal just to reach the $40 \%$ target reduction for carbon-dioxide emissions by 2030, if doing so entails even weaker macroeconomic and fiscal outcomes in the future.

In September of 2014, a Commission for Environmental Tax Reform(Comissão para a Reforma da Fiscalidade Verde, CRFV, hereafter), appointed by the Portuguese government earlier in the year, submitted a report containing a proposal for a package that was designed to guide Portugal to a triple dividend in the long run (see CRFV, 2014).Then, in November 2014, upon government proposal, the Parliament approved a new carbon tax, to take effecton January $1^{\text {st }} 2015$, which ignored many of the key characteristics proposed by the CRFV Commission.

The objective of this note is to presentsimulation results on how far is what was approved by the Portuguese Parliament from what was proposed by the CRFV Commission. We show that a carbon tax in Portugal is needed, and it can be virtuous in the long run, that is, it can yield the second and the third dividends, but only if it is done right. Furthermore, we present evidence that what was approved byParliament falls short of these objectives.In fact, authorities proved to be unwilling to commit to earmarking carbon-tax revenues towards the most efficient recycling alternatives, or to any energy-efficiency objectives, for that matter, or even to simply recycle the carbon tax revenues after 2015. The economic and budgetary consequences are clear: as approved, the new carbon tax will ultimately fail to deliver on the second and the third dividends.

The simulation results on the environmental, macroeconomic, and budgetary effects of a new carbon tax were obtained with a dynamic general-equilibrium model of the Portuguese economy. This model incorporates fully-dynamic optimization behavior, and features an endogenous-growth mechanism,as well as a detailed modeling of the public-sector account, both in 
terms of spending and in terms of taxes and contributions. It is worth highlighting that all major tax bases are fully endogenous, a feature that is crucial to seriously evaluate any tax reform package.

Previous versions of this model were used to evaluate the impact of alternative tax policies (see Pereira and Rodrigues, 2002; 2004), public pension reform (see Pereira and Rodrigues, 2015), and other energy and climate policies (see Pereira and Pereira, 2013; 2014a;2014b). Even more crucial from this note's perspective, this model served as the basis for the Commission's recommendations, and all results presented here are, although naturally in a different context, includedin its official report (see CRFV, 2014).Accordingly, the key contribution of this article is to provide answers to a well-defined policy question in a well-defined public policy situation, answers which were instrumental in the actual framing of the proposals by the CRFV Commission and the carbon tax, as it was eventually adopted. From a conceptual standpoint it connects the introduction of a carbon tax to its economic and budgetary effects, something that makes its interest much more than parochial, as many economies struggle with the dual woes of low growth and high public indebtedness.

The remainder of this note is structured as follows. Section 2 describes the dynamic generalequilibrium model used. Section 3 summarizes and discusses the significance of the simulation results. Section 4 concludes with policy recommendations.

\section{Methods and Data}

To determine the long-term environmental, economic, and budgetary effects of a carbon tax in Portugal, we use a dynamic general-equilibrium model that features an energy sector, endogenous growth, and a detailed public sector. Pereira and Pereira (2012, revised in 2014) provide a full account of the model's equations, parameters, data, calibration, and numerical implementation. What follows is, necessarily,only a very general description. 


\subsection{A General Description of the Model}

In a decentralized economy framed in real terms, all agents are pricetakerswith perfect foresight. The production sector, the household sector and the public sector are fully endogenous, while the foreign sector is not. Capital is not fully mobile as the accumulations of the different types of capital are subject to investment-specific adjustment costs.

The economy's trajectory is given by the optimal evolution of eight stock and five shadowprice variables - private capital, wind-energy capital, public capital, human capital, and public debt,and their respective shadow prices, along with foreign debt, private financial wealth, and human wealth. In the long run, growth is endogenous, and is driven by the optimal accumulation of private capital, public capital and human capital, the last two of which are publicly provided.

The intertemporal path for the economy is determined by behavioral equations and marketequilibrium conditions. The product market equalizes demand and supply for output. Part of domestic demand is satisfied with foreign production. The balance of payments is highly stylized. Domestic production and imports are absorbed by domestic expenditure and exports. Net imports include fossil fuels, and are financed through foreign transfers and foreign borrowing. As a small open economy, Portugal obtains financing at a rate determined in international financial markets. In turn, labor-market clearing incorporates an exogenous structural unemployment rate. Finally, financial-market equilibrium reflects the fact that private-capital formation and public indebtedness are financed by household savings and foreign financing.

The model is implemented numerically using detailed macroeconomic data and parameters sets for the period covering 2000-2013.This reflects the most recent available information and covers several business cycles, reflecting the long-term nature of the model. Stock variables are set at 2013 levels.Whenever possible, parameters are set from data sources or the literature, or are obtained by calibration, i.e., extrapolating, as the steady-state trajectory, the trends for 2000-2013. 


\subsection{On the Behavioral Components of the Model}

Aggregate output has a CES technology that links value added to primary-energy demand.In turn, value added is Cobb-Douglas with constant returns to scale in the reproducible inputs effective labor, i.e., labor demand adjusted by human capital, private capital, and public capital. See Figure 1.Investment and labor-demand schedules are chosen tomaximize the present value of thenet cash flows, subject to the equation of motion for private capital that is subject to depreciation.Investment is dynamic and induced by strictly-convex adjustment costs associated to learning and installation that are internal to the firm. Public infrastructure and knowledge are publicly-financed positive externalities, and, without public investment, decreasing returns set in. The cash flow is net of all relevant corporate-income and payroll taxes, as well as any investment-tax credits, and at the end of each operating period this cash flow is transferred back to the households.

$<$ Insert Figure 1 here $>$

Optimal primary-energy demand is such that it maximizes the present value of the net cash flows. Primary-energy demand is a CES aggregate of crude oil and non-transportation fuels. Petroleum products dominate in transportation, while coal, natural gas andwind energyrule in electric power and industry. With a greater potential for substitution, the latter fuels are assumed to be Cobb-Douglas. See Figure 1. Crude oil, coal, and natural gas are all imported.Wind-energy investment is subject to adjustment costs while wind turbines depreciate. Energy efficiency is modeled exogenously as a productivity-enhancing factor in the use of the different types of primary energy.

Upon combustion, fossil fuels release carbon into the atmosphere. In accordance with the Intergovernmental Panel on Climate Change (2006) reference approach, the demand for fossil fuels 
is converted linearly into carbon emissions. Together, the amount of fuel consumed, along with its carbon factor, its oxidation rate, and the ratio of the molecular weight of $\mathrm{CO}_{2}$ to carbon are all used to compute how much $\mathrm{CO}_{2}$ is emitted. The relative abundancy of carbon in each hydrocarbon can be used to determine how much carbon the different fossil fuels emit per unit of energy. For each ton of oil equivalent consumed, Pereira and Pereira (2015a) find that crude oil yields $3.04 \mathrm{tCO}_{2}$, bituminous coal yields $3.78 \mathrm{tCO}_{2}$, and natural gas yields $2.34 \mathrm{tCO}_{2}{ }^{1}$

Households, in an overlapping-generations setting with a finite but non-deterministic planning horizon, choose consumption and leisure streams to maximize intertemporalsubjectivelydiscounted lifetime-expected utility, subject to a consolidated budget constraint. Preferences are CES and additively separable in consumption and leisure. Consumption is subject to value-added and excise taxes, and a budget constraint ensures thatthe households' expenditure stream, discounted at the after-tax market real interest rate,remains below total wealth. Wealth is made up of human wealth, net financial worth, and the present value of all firms.Household's income includes public transfers, international transfers, net interest payments received on public debt, and net profits distributed by corporations. Human wealth reflects the present discounted value of future labor income, net of personal-income taxes and social security contributions. Households decide how much labor to supply, where their wages are affected by the stocks of knowledge and human capital that are augmented through public investment.Spending includes consumption, taxes and paying off debts to foreigners. Income, net of spending, adds to net financial wealth.

As to the public sector, public debt has a dynamic equation where the excess of public spending over all tax revenues and contributions has to be financed with furtherborrowing. Tax revenues include value-added and excise taxes,personal-income taxes, corporate-income taxes, and

\footnotetext{
${ }^{1}$ Similar to what occurs in other OECD countries in Europe, manufacturing and power generation in Portugal are the two most polluting sectors. In Portugal, however, households, manufacturing, agriculture, forestry and fishing release more $\mathrm{CO}_{2}$ in relative terms, while power generation, transportation and storage are relatively more energy efficient.
} 
Social Security contributions paid by firms and workers. All taxes are levied on endogenouslydetermined tax bases. Residual taxes are lump sum, and grow exogenously.Interest payments service public debt, and households benefit from public transfers such as pensions, unemployment subsidies, and other social spending that grow exogenously. In addition, there ispublic consumption and public investment both in human capital and in infrastructures. Public investments are subject to depreciation and strictly-convex adjustment costs, and constitute an engine of endogenous growth. Along with public consumption, the public sector chooses themtomaximize social welfare, defined as the net present value of the future stream of utility. These optimal choices are constrained by the dynamic equations for public debt, human capital and infrastructures.

\section{Results and Discussion}

This section is a commented walk through a sequence of simulation results, aimed at presenting evidence of three facts: a carbon tax in Portugal is needed, it is possible to design a reform package that achieves the triple dividend in the long run, and, finally, what was approved by Parliament, and became law in 2015,fails to achieve the three dividends.

\subsection{The Reference Case: Why a Carbon Tax is Necessary}

The starting point for the exercise has necessarily to be the identification of the relevant target reduction in carbon emissions over time. While no specific target was specified, the Commission decided to work with $40 \%$ reduction in carbon dioxide emission by 2030 , relative to 1990 levels, as an indicative goal. This goal was consistent with the official pronouncements of the Portuguese government, as well as Portugal's international commitments (see, for example, the national roadmap to low carbon in 2050 from APA, 2012, or the policy framework for climate and energy from 2020 to 2030 from the European Commission, 2014a). This objective was recently 
confirmed as the common EU-28 Intended Nationally Determined Contributions (INDCs) for the December 2015 COP 21 in Paris(see European Commission, 2015b).

So, what would likely happen in Portugal in terms of carbon emissions without a carbon tax? The Reference Case is the answer to this question. Without a surcharge on the goods and services produced, in accordance with their carbon content, fossil-fuel emissions will probably still fall over time, on account of two ongoing trends.

The first trend affecting emissions is the expected evolution of the fossil-fuel prices. The CRFV Commission considered three alternative scenarios for the future of international prices of coal, oil and natural gas (see Esteves, 2014, for details). The first scenario is based on projections made by the European Commission (2014c) and has the price of oil rising, relative to natural gas. At the other extreme, there is a scenario based on the middle of 2014 futures prices in the Intercontinental Exchange, and which has the price of oil falling relative to natural gas. The reference scenario adopted by the CRFVCommissionis obtained as the midpoint of the first two scenarios.According to the central fossil-fuel price scenario forecasts, by 2030, crude oil is expected to be $11 \%$ more expensive than in 2013 , coal by $20 \%$, and natural gas by $26 \%{ }^{2}$

The second ongoing trend that drives emissions is domestic energy-efficiency gains.A series of EU directives have set goals for energy efficiency. Most notably, EC Directive 2009/28/ECset a legally-binding target of increasing energy efficiency by $20 \%$ by 2020 , relative to 1990 levels(European Commission, 2013;2014a;2014b). Recent EU legislation and discussions suggest even more ambitious targets, aiming, for example, at a $40 \%$ reduction in primary-energy use by

\footnotetext{
${ }^{2}$ Currently, the spot price of West Texas Intermediate crude is around $\$ 30$ a barrel. Globex futures for this commodity for delivery in December of 2016 trade at around $\$ 39$ a barrel, while the corresponding prices for 2020 and 2024 are around $\$ 47$ and $\$ 50$, respectively. These figures suggest that market participants do not expect the price of crude oil to remain at its low current level. A global glut and a weak overall demand are two cyclical factors that keep the present price contained. Over the long run, i.e. given enough time to adjust, structural factors such as peak oil and emerging markets resuming economic growth are expected to give support to a persistently-higher price of crude oil. It is also worth mentioning that situations of an oversupply of crude tend to be resolved over time through lower capital investment in the energy sector, as we're seeing now with Canada's oil-sands complex.
} 
2030, relative to 1990(European Commission, 2014a;2014b). In both cases, the average annual gain in energy efficiency over the next two decadeswill have to be around $2 \% .^{3}$

Table 1 shows that, together, these two ongoing trends are expected to reduce emissions by as much as $21.7 \%$, by 2030 , in relation to their 1990 levels. This proves that a carbon tax is needed, given that, in the Reference Case,only a little more than half of the $40 \%$ reduction target will be reached. Even by 2050, $\mathrm{CO}_{2}$ emissions will only have fallen by around one third.

\section{$<$ Insert Table 1 here $>$}

As the pre-carbon-tax scenario, the Reference Case is also instrumental to identify the existence and to measure thestrength of the second and third dividends. In particular, if by recycling carbon-tax revenues back into the economy in the form of lower distortionary tax margins, the levels of employment and GDP rise above those attained in the Reference Case, then we have a strong realization of the second dividend. Similarly, if, with recycling, the ratio of public debt to GDP is lower than in the pre-carbon-tax scenario, then we have a strong realization of the third dividend, which pertains to public finances. ${ }^{4}$

\subsection{The Commission's Proposal: Achieving the Three Dividends}

\footnotetext{
${ }^{3}$ In our modelling approach we do not explicitly consider the costs of achieving the $2 \%$ energy-efficiency gains. This is consistent with the fact that there are readily-available cost-effective energy-efficiency opportunities in the economy (see, Seixas and Fortes, 2014). Nevertheless, given that we ignore their costs, the environmental, economic and budgetary benefits of their adoption we identify should be understood as an upper bound. This is not a matter of concern since the nature of our policy exercise to be presented below is to measure the incremental effects of additional energy-efficiency gains assumedly financed through the carbon tax revenue-recycling mechanisms.

${ }^{4}$ In the discussion that follows, we assume the reference scenarios of the CRFV Commission for both the evolution of the fossil-fuel prices and the evolution of energy efficiency. See Pereira and Pereira (2015a) for detailed sensitivity analysis with respect to alternatives to both reference scenarios. Naturally, the magnitude of the effects changes with difference assumptions. For example, for any given level of carbon taxation, the more fuel prices increase or the more energy efficiency gains increase, the more $\mathrm{CO}_{2}$ emissions fall. The main results about the issue of the realization of the three dividends, however, are not dependent on the specific scenarios under consideration. This is because, the effects of recycling are always cumulative to whatever effects are observed under the reference scenario.
} 
The Commission for Environmental Tax Reform (CRFV, 2014)proposed a carbon tax that is designed to achieve a strong realization of the three dividends, at least in the long run. As further detailed in Pereira and Pereira (2015b), to simultaneously ensure a reduction in GHG emissions, along with improved macroeconomic performance, and a stronger budgetary position, we have to consider mixed recycling strategies, where the carbon-tax revenues are used not only to alleviate various distortionary tax margins that are key to economic growth, but are also used to actively promote consistent gains in terms of further energy efficiency.

An important consideration on the design of a new carbon tax is the fact that a significant part of carbon-dioxide emissions in the Portuguese economy are already covered by the European Union's Emissions Trading System (EU-ETS). Sectors that are totally covered by the EU ETS include the production and distribution of electricity, as well as the manufacture of coke, of chemicals, and of paper and pulp. The manufacture of other nonmetallic products is partially covered. When all regulations and exceptions are taken into account, the emissions covered by the EU ETS correspond to almost 37\% of the total in 2012 (see Tables 19 and 20 of CRFV, 2014). The four most significant sectors that are not covered by the EU-ETS include transportation, construction, health and social-work activities, and wholesale and retail trade.In light of the above, only those sectors not participating in the EU-ETS are to be subject to a carbon tax. In addition, and to avoid distorting market incentives, across EU-ETS and the remaining sectors, the CRFV Commission opted to index the carbon tax to the EU-ETS. ${ }^{5}$

Following the official EU projections for the EU-ETS carbon prices (see European Commission, 2014c), it is assumed that the carbon tax starts at $6 \mathrm{EUR} / \mathrm{tCO}_{2}$, and will rise to 10

\footnotetext{
${ }^{5}$ The fact that ours is an aggregate model implies that the responsiveness to carbon prices is the same between ETS and non-ETS sectors. In fact, it is likely - although there is no clear evidence for the Portuguese case - that the ETS sectors will be more responsive to carbon pricing. This implicit assumption is, however, not as strong as it may seem. This is because the average responsiveness in the economy can be seen as a convex combination of the responsiveness in both ETS and non-ETS sectors, and the ETS sectors correspond to about $37 \%$ of emissions. Accordingly, the economy-wide responsiveness is much closer to the responsiveness of the non-ETS sectors. Nevertheless, this also suggests that the effects we identify on emissions should be regarded as an upper bound which, even if slightly, overestimates the actual effects of carbon pricing.
} 
$\mathrm{EUR} / \mathrm{tCO}_{2}$ by 2020 , leveling off at $35 \mathrm{EUR} / \mathrm{tCO}_{2}$ from 2030 onwards. While the $\mathrm{EC}$ actually projects EU-ETS carbon prices to reach 100 euros per ton by 2050, the CRFV Commission decided to follow a more conservative approach and assumed constant carbon prices after 2030 at 35 euros per ton.

The average price for $\mathrm{CO}_{2}$ emissions allowances between 2006 and 2011 was 15 euros, having reached a maximum of 34 Euros. In more recent years, prices have reached rather low levels over weak aggregate demand - 8Euros per tCO2 in 2012, 4.7 Euros in 2013, and about 6 Euros in 2014.Future prices are projected endogenously in order to meet the cumulative emissions cap. A linear reduction factor reduces this cap. As a result, the annual volume of available EU-ETS allowances is assumed to decrease by $1.74 \%$ each year. Until the mid-2020s, ETS prices increase at a slower pace on account of a significant allowance surplus. From the mid-2020s onward, ETS prices are expected to accelerate, as emissions are projected to exceed a continuously-decreasing supply of available allowances.

Let's consider, finally, two important practical implementation points in terms of the magnitude of the carbon tax and the magnitude of the revenues eventually available for recycling. First, given the one-sector nature of our model and given that the carbon tax affects only the nonETS sectors, we adjust the overall carbon tax levied on the economy by the size of the non-ETS sectors, i.e., a factor of .63. Hence, a carbon tax of say 15 Euros on the non-ETS sectors is modeled as a tax of 9.45 Euros on the overall economy. Second, the revenues from the auctioning of carbon emission permits under the ETS are not considered or included in the revenues to be recycled. Mandatory auctions of permits only started in 2013 and the revenues generated thereby are earmarked to reduce the electricity-tariff deficit. 
Table 2 shows that, by 2030, the Commission's proposalwould lower $\mathrm{CO}_{2}$ emissions by $38.54 \%$ in relation to 1990 levels, within striking distance of the GHG-emissions target. ${ }^{6}$ Naturally, the effects of the carbon tax would continue thereafter, and, by 2050, thereductions would reach $48.31 \%$ of the 1990 emission levels.

$<$ Insert Table 2 here $>$

Having experimented with several alternative recycling strategies, the CRFV adopted one where, of all carbon-tax revenues raised, $50 \%$ are spent on investment tax credits (ITC), 25\%are used to alleviate Social Security contributions (SSC) paid by employers, and 25\%go to finance lower personal-income taxes (PIT).

It is important tomention that part of the carbon tax revenuesto be recycled as lower distortionary tax margins, as described above, is designed to be allocated towards financing energyefficiency activities, specifically to promote activities ${ }^{7}$ that could result in a consistent additional $1 \%$ annual gain in terms of energy efficiency (for the specifics surrounding these tax changes, see CRFV, 2014). ${ }^{8}$ Seixas and Fortes (2014) suggest that energy-efficiency improvements equivalent to average annual savings in primary-energy consumption of $2.5-2.9 \%$ are cost effective, even in the absence of further policies.In spite of this evidence, adopting energy-efficiency enhancing technologies is usually very slow and limited in the absence of public incentives (see, for example, Gerarden et al.,

\footnotetext{
${ }^{6}$ It is worth reiterating that when the government appointed the CRFV Commission, no specific target was set for reductions in carbon emissions. In this setting, the Commission decided to work with the 40\% reduction by 2030, compared to 1990 levels, as an indicative goal, given Portugal's international commitments. In this vein, the Commission proposed alternative mechanisms to reach reductions around this objective.

${ }^{7}$ In terms of the corporate income tax, this includes, for example, investment tax credits for energy-efficient high-heat furnaces, thermal-integrity heat pumps, an increasing use of co-generation, and a greater reliance on natural gas in industrial furnaces. In terms of personal-income tax, credits could be directed towards the purchase of more energy-efficient devices and durables, such as LED lighting, thermal-integrity windows, and hybrid as well as electric vehicles.

${ }^{8}$ The higher carbon price implied by the carbon tax should in itself induce the adoption of some energy-efficiency measures. This effect of carbon taxation is not captured by the model. The main effects we explicitly capture are the fuel-switching effects (substitution effects) and the energy-demand effects (volume effects).
} 
2015a; 2015b, and Newell and Siikamaki, 2015). The use of carbon tax revenues to target energyefficiency would provide the legal framework and necessary incentives to lead to their adoption (see, for example, Gillingham, Newell and Palmer, 2004).9

Using an international benchmark, ${ }^{10}$ we determined that achieving a persistent annual increase in energy efficiency of about $1 \%$ of the total primary-energy consumption would require an investment of 85-100 million euros each year (see Pereira and Pereira, 2015b). For reference, under our specification, the expected carbon tax revenues are estimated at 312 million by 2020 and 834 million by 2030 (see Table 3 of Pereira and Pereira, 2014d). Accordingly, only a relatively small part of the carbon tax revenues - about one-third by 2020 and about one-eighth by 2030 - wouldneed to be linked to activities that improve energy efficiency. This leaves ample room for adjustments based on the observed effects of the policies should the actual cost of achieving these goals exceed the values projected based on the international standards above.

Table 3 presents the impact of the Commission's proposal (see the row in bold). Note how a strong realization of the triple dividend is achieved by 2050, with long-term $\mathrm{CO}_{2}$ emissions falling by $48.31 \%$ in relation to their 1990 levels, withthe levels of employment and of GDP0.26\% and 0.68\% higher than in the pre-carbon-tax scenario, and, finally, with the ratio of public-debt-to-GDP 1.47 pp lower. Also, we conclude that it takes time for all three dividends to materialize.Indeed, by 2030, while the first dividend has already been achieved, the detrimental effects of thecarbon tax on employment and GDP are just close to being neutralized, although not yetreversed, and the third dividend is substantially less pronounced than twenty yearslater. ${ }^{11}$

${ }^{9}$ It should be highlighted that the energy-efficiency measures considered here are not financed in a way that is separate from and would thereby compete with the different recycling mechanisms. Their financing is actually embedded in the different tax margins considered for the purpose of recycling the carbon tax revenues.

${ }^{10} \mathrm{As}$ a reference point, 400 million euros is the investment required to generate 1,000 Ktoe of energy-efficiency savings. This value is based on the average cost of avoided energy consumption at the industrial price in the US of $\$ 13.8$ per MMBTU, presented in the abatement cost structure in Granade et al. (2009).

${ }^{11}$ Naturally, the magnitude of the economic and budgetary effects of $\mathrm{CO}_{2}$ taxation - although not the realization of the second and third dividends - is sensitive to the assumptions about the substitutability between value added and energy inputs and among different energy inputs. Extensive sensitivity analysis shows the magnitude of the effects to be more sensitive to the elasticity of 


\section{$<$ Insert Table 3 here $>$}

It is interesting to see how the Commission's proposal combines the best characteristics of two more elementary mixed strategies. In particular, the case (see the first row) where more carbontax revenues (50\%) are allocated to reducing personal-income taxes (PIT)results in a comparatively larger increase in the levels of employment and GDP than the case that lowers payroll taxes (SSC). This is because labor demand is more elastic than labor supply, probably because, to some extent, firms can substitute capital for labor, and wages are most households' primary source of income. On the other hand, the case where the ratio of public-debt-to-GDP is reduced the most is where payroll taxes are lowered (see the second row). We can conclude that the $50 \%, 25 \%$ and $25 \%$ allocation of carbon-tax revenues to each of the three tax margins was chosen by the Commission given the significance of the investment tax credit, and the attempt to find an acceptable point on a trade-off between a lower PIT that expands employment, but fails to yield much of a third dividend, and a lower SSCthat is comparatively better at fiscal consolidation than at job creation.Thismixed-strategy allocation is fully in line with recenttax-policy recommendations (see, for example, OECD, 2014; and Eurogroup, 2014).

\subsection{What Parliament Ultimately Approved: Failure to Deliver}

In the last quarter of 2014, with the Commission's final report in hand, the Portuguese Parliament approved a new carbon tax that was enacted on January $1^{\text {st }} 2015$. To the dismay of many, most of the key characteristics of the environmental tax reform package that the Commission had proposed were now absent.Although the new carbon tax was still indexed to the EU-ETS, the

substitutionbetween value added and energy, than that amongst energy inputs. A lower elasticity of substitution implies that a greater degree of emissions reductions must originate in reduced output, as opposed to substituting away from fossil fuels in production. A higher tax is thus required to reach lower emissions targets and the negative impact on GDP is naturally more significant. This higher tax generates greater revenues that lower the level of public debt (see section 5.6 of Pereira and Pereira, 2014c, for details). 
commitment to direct the tax changes towards promoting consistent gains in energy efficiency had disappeared, as had the commitment to recycle all revenues back into the economy by alleviating key distortionary tax margins. In fact, with parliamentary elections scheduled for the same year, 2015, it was decided that carbon-tax revenues would only be recycledonce, and in the form of lower personal-income taxes.

Specifically, the most salient characteristics of the new carbon tax,as compared to what was proposed by the Commission, are as follows. First, there is no assignment of carbon tax revenues to investment tax credits or reductions in social security contributions. All revenues are recycled through reductions in the personal-income tax. Second, the reductions in the personal-income tax considered are in no way connected to objectives of promoting energy efficiency.Third, recycling itself is only explicitlymandated for 2015. There is no legally binding obligation to recycle the carbon tax revenues after 2015, i.e., these revenues can be utilized as part of the general funds for general purposes.Under these circumstances, the revenues from carbon taxation will revert to the general budget and will be allocated just like any other revenue. Introducing a carbon tax is, then, just an increase in distortionary taxation, without any of the redeeming features in terms of alleviating other tax margins that, jointly, have the potential of generating the second and third dividends.

To ascertain how far is what was approved from what was proposed,we examine a series of cases (see Table 4)that allow us to trace how the long-term simulation results change when we move, step by step, away from what the Commissiondesigned,towhat will soon become reality.

\section{$<$ Insert Table 4 here $>$}

As discussed above, the CRFV Commission's plan achieves a strong realization of the triple dividend, i.e., in relation to the Reference Case (the pre-carbon-tax scenario), GHG emissions are 
reduced, levels of employment and GDP are increased, and the ratio of public debt to GDP is lowered. In contrast, if what was approved is not amended, only $\mathrm{CO}_{2}$ emissions will be reduced, and, even then, by not as much as needed to reach the $40 \%$ target reduction by 2030, in relation to 1990 levels. In addition, the carbon tax, as approved, will induce detrimental economic and budgetary effects, that is, it will fail to achieve the second and third dividends.

In the long term, by 2050, whenITC, SSC, and PIT recycling are replaced with just PIT recycling, relative to the effects under the CRFV plan, the level of GDP falls and the ratio of public debt to GDP increases. Greenhouse-gas emissions fall because of less economic activity and the level of employment rises because more recycling now goes to alleviate PIT. Given that labor demand is more elastic than labor supply, a personal-income-tax-induced expansion in the labor supply schedule will generate more jobs.

When, in addition to the exclusive focus on PIT recycling,there are no further energyefficiency gains, carbon-dioxide emissions reductions fall significantly, the level of GDP falls even more, and public finances deteriorate, again.Interestingly, the level of employment is unaffected. ${ }^{12}$

Finally, when the recycling of carbon-tax revenues is limited to alleviating PIT,and only in 2015, i.e. when, in practice, the recycling of revenues beyond that year does not take place, the levels of employment and of GDP suffer, public indebtedness mounts, and carbon-dioxide emissions are only marginally lower due to weaker macroeconomic activity.

By comparing the results of the carbon-tax reform that was approved by Parliament with those of the package proposed by the CRFV Commission appointed by the Portuguese government, we conclude that, in the long term, the carbon-dioxideemissionsreductions are 2.65 pp lower than

\footnotetext{
12 It should be mentioned that this is a critical component of the package proposed by the Commission as it provided much-needed funding to incentivize the adoption of energy-efficiency opportunities that exist, but that are well known as being slow to being adopted in the absence of public incentives.
} 
they could be, the levels of employment and of GDP are 0.83 and 2.23 pp lower, respectively, and the ratio of public debt to GDP is 5.43 pp higher. ${ }^{13}$

This means that, whilethe first dividend of the carbon taxis somewhat weaker than it would otherwise be, with what was ultimately approved, the second and the third dividends disappear, as both the levels of employment and GDP are now below those of the Reference Case, and the ratio of public debt to GDP is several percentage points higher.

To summarize, the new carbon tax in Portugal, in the form it was approved by the Portuguese Parliament, fails to deliver on the triple dividend. Specifically, there is less of the first dividend, andthere is no basis whatsoever for the second and third dividends to materialize. Furthermore, it is clear that the two main reasons for these less-favorable resultsacross the board, compared to what was proposed, are the lack of revenuerecycling and,therefore,alsothe lack of energy-efficiency objectives. The merechange from the mixed strategy proposed by the Commission to an exclusive focus on the personal-income tax, while reducing the realization of the threedividends, would not lead to such a dramatic reversal.

\section{Conclusions and Policy Implications}

We have presented evidence that a carbon tax is needed if, by 2030, Portugal is to reach the $40 \%$ target it committed itself to, in terms of reducing $\mathrm{CO}_{2}$ emissions in relation to their 1990 levels.Furthermore, a carbon tax can be virtuous, in the sense that a strong realization of the triple dividend can be achieved. This means that, in the long term, simultaneously, GHG emissions can be reduced, macroeconomic performance can be improved, and public finances can be strengthened. But this positive outcome will only materialize if carbon-tax revenuesare recycled, i.e. if they are used

\footnotetext{
${ }^{13}$ It should be noted that in our model, public spending is endogenous and, therefore, it is not constant. For this reason, one would not expect lower public indebtedness just because carbon-tax revenues are not recycled back into the economy in the form of lower distortionary tax margins. In fact, even if public expenditures were exogenously fixed in the model, such a reduction in debt would not automatically occur either, since the new carbon tax would have a negative effect on the economy and shrink the tax base.
} 
to promote sustained gains in terms of energy efficiency, and, at the same time, to alleviate various key distortionary tax margins.

A new carbon tax in Portugal with none of the key characteristics needed to ensure a triple dividend was enacted at the beginning of 2015. Authorities were unwilling to commit to earmarking carbon-tax revenues towards the most effective recycling alternatives or to any energy-efficiency improvement activities. In 2015, the extra carbon-tax revenues were exclusively directed to lower personal-income taxes, while the decision to even recycle for subsequent years was left wide open.The economic and budgetary consequences are clear: the new carbon tax will likely have detrimental effects on both economic and budgetary performance as the counterpart of its possible environmental success. The new carbon tax will ultimately fail to deliver on the second and the third dividend. ${ }^{14}$

The problem may, however, turn out to be even more complex. In fact, because of a number of serious practical shortcomings in its implementation, the positive environmental impact of the new carbon tax could prove to be even smaller than what we simulated, at least in the short run. In its current configuration, rather than being an autonomous levy, the new carbon tax in Portugal isa component of the tax on petroleum products (ISP). The new carbon tax is as hidden and as invisible as a value-added tax. Furthermore, as part of the ISP, it is subject to all types of exemptions that are counterproductive from an environmental perspective. This means that, because the public is largely unaware of its current magnitude, and seems to be completely obliviousto the sharp increase that is built-in for the near future, it is reasonable to conclude that theirbehavior is unlikely to change very much, making it rather difficult for GHG emissions to fall very significantlyover the coming years.

\footnotetext{
14 Political economy considerations can account for what happened as the environmental tax reform was effectively bundled with a totally separate reform of the personal-income-tax system which contemplated a reduction in personal-income taxes. There are, however, two other plausible explanations for why the revenue-recycling part of the Commission's proposal was not formally mandated after 2015. First, the government may have wanted the luxury of extra fiscal space. Second, and in line with Bovenberg (1999), it may have been concerned with the distributional consequences of adopting the most efficient revenue-recycling options. Ensuring a subsistence level of polluting consumption, Klenert and Mattauch (2016) find that a well-designed policy can achieve the double dividend and still avoid the regressivity of a carbon tax, the main driver of which is a price increase of carbon-intensive goods such as electricity, heating and food, for which subsistence levels exist (Grainger and Kolstad, 2010).
} 
Therefore, even a meaningful realization of the first dividend - anenvironmental dividend - isnot a foregone conclusion.

The policy recommendations are clear. To increase the probability of reaching the 2030 target for emissions reductions, and to ensure the realization of a triple dividend associated with the introduction of a carbon tax, Portugal needs to act on three fronts, and urgently amend the law it approved in late 2014. First, it must pass legislation that not only separates the indexed carbon tax from the tax on petroleum products,but also makes it totally comprehensive and visible to the public at large.Second, it must enshrine, as a principle, that all carbon-taxrevenues are to recycled back into the economy in the form of lower tax burdens, and back into the environment in the form of financing activities aimed at obtaining further energy-efficiency gains on a consistent basis. Third and finally, the new law must stress that, in order to achieve a more robust triple dividend in terms of better long-term environmental, macroeconomic and budgetary outcomes, there is a need for a mixed revenue-recycling strategy that lowers personal-income taxes, lowers employers' payroll contributions, and increases investment tax credits,andall these have to be closely linked to further promoting energyefficiency. ${ }^{15}$

The longer it takes the Portuguese Parliament to amend the current law, the greater the cost, given that the international price per ton of $\mathrm{CO}_{2}$ isprojected to be on an uptrend, and both macroeconomic performance and budgetary consolidation continue to show great debilities, in general. It is therefore crucial that the several problems we highlighted in this note be acknowledged and corrected, sooner rather than later.Whatare relatively painless mechanisms for achieving theenvironmental targets, if adoptednow, will soon become rather painful, if one waits for too long.

\footnotetext{
${ }^{15}$ As energy-efficiency recycling is embedded in the different recycling mechanisms, abandoning recycling means also abandoning energy-efficiency measures. So, if pressed to recommend one improvement, we would choose dedicated revenue recycling. Just adopting dedicated revenue recycling, however, without including energy-efficiency measures seems to leave untapped many important potential environmental, economic, and budgetary benefits. This said, a more comprehensive modeling and analysis of energy-efficiency improvements is one of the key areas for future work as far as environmental tax reforms in Portugal is concerned.
} 
Besides, now is the time to seize the opportunity both to secure the recent progress in terms of fiscal consolidation, and to jumpstart economic growth.

Acknowledgments: This note is a by-product of work developed for the Commission for Environmental Tax Reform (Comissão para a Reforma da Fiscalidade Verde, CRFV) appointed in early 2014 by the Portuguese government. We would like to thank Jorge Vasconcelos, the Head of the Commission, and JúliaSeixas for very stimulating discussions. In addition, we would like to thank the Editor as well as two anonymous referees for several very insightful comments, suggestions and calls for further clarification. The usual disclaimer applies: this paper exclusively reflects the views of its authors, and these views do not necessarily coincide with those of the CRFV Commission.

\section{References}

Agência Portuguesa do Ambiente [APA], 2012. A NationalRoadmap to LowCarbon 2050.Ministério da Agricultura, do Mar, do Ambiente e do Ordenamento do Território. Lisboa, Portugal.

Aldy, J. and Stavins, R., 2012. The Promise and Problems of Pricing Carbon: Theory and Experience, The Journal of Environment Development, Vol. 21, No. 2, pp. 2152-2180.

Bovenberg, A., 1999. Green Tax Reforms and the Double Dividend: An Updated Reader's Guide, International Tax and Public Finance, Vol. 6, pp. 421-443.

Comissão para a Reforma da Fiscalidade Verde [CRFV],2014. Projecto de Reforma da Fiscalidade Verde. Ministério do Ambiente, do Ordenamento do Território e da Energia. Lisboa: Portugal.[http://bitly.com/1oYw32X.]

Esteves, P.,2014.Cenário da Evolução do Preço dos Combustíveis: Anexo II do Relatório Técnico

'Sobre os Efeitos Ambientais e Económicos de uma Nova Tributação sobre o Carbono em Portugal', Relatório Técnico apresentado à Comissão de Reforma da Fiscalidade Verde. Lisboa, Portugal.

European Commission Directive 2009/28/EC of the European Parliament and of the Council.April $23^{\text {rd }}$. [http://bit.ly/1PUIyJN.] 
Eurogroup, 2014.Structural Reform Agenda - Thematic Discussions on Growth and Jobs Reduction of the Tax Wedge.Press Statement. July $8^{\text {th }}$. [http://bit.ly/1JezAl5.]

European Commission [EC], 2013.Green paper - A 2030 Framework for Climate and Energy Policies.COM(2013) 169 Final. March 27 ${ }^{\text {th }}$. Brussels. [http://bit.ly/1AEfgrF.]

European Commission[EC], 2014a. Impact Assessment Accompanying the Document 'Communication from the Commission to the European Parliament, the Council, the European Economic and Social Committee and the Committee of the Regions: A Policy Framework for Climate and Energy in the Period from 2020 up to 2030'. Commission Staff Working Doc. SWD(2014) 15 final.January 21 ${ }^{\text {st. Brussels. [http://bit.ly/1eGufri.] }}$

European Commission[EC], 2014b.Communication from the Commission to the European Parliament, the Council, the European Economic and Social Committee and the Committee of the Regions: A Policy Framework for Climate and Energy in the Period from 2020 up to 2030.COM(2014) 15 Final.January 21 ${ }^{\text {st }}$. Brussels. [http://bit.ly/1LUcJKL.]

European Commission[EC], 2014c.EU Energy, Transport, and Emissions Trends to 2050 Reference Scenario 2013.Directorate General for Energy, Directorate General for Climate Action, and Directorate General for Mobility and Transport. Brussels.[http://bit.ly/1dDkpXd.]

European Commission[EC], 2015a.Statistical Annex of the European Economy - Fall 2015, Directorate General for Economic and Financial Affairs. Brussels.

European Commission[EC], 2015b.Submission by Latvia and the European Commission on Behalf of the European Union and Its Member States, March 6 ${ }^{\text {th }}$ 2015.[http://tiny.cc/ls435x.]

Gerarden, T., Newell, R., Stavins, R., and Stowe, R., 2015a.An Assessment of the Energy-Efficiency Gap and Its Implications for Climate-Change Policy, National Bureau of Economic Research Working Paper 20905.

Gerarden, T., Newell, R., and Stavins, R.,2015b.Assessing the Energy-Efficiency Gap, National Bureau of Economic Research Working Paper No. 20904.

Gillingham, K., Newell, R., and Palmer, K., 2004. The Effectiveness and Cost of Energy Efficiency Programs, Resources, Resources for the Future, October $21^{\text {st }}$, pp. 22-25.

Goulder, L., 1995. Environmental Taxation and the 'Double Dividend': A Reader's Guide. International Tax and Public Finance, Vol. 2, No. 2, pp. 157-183. 
Goulder, L., Parry, I., and Burtraw, D., 1997. Revenue-Raising Versus Other Approaches to Environmental Protection: The Critical Significance of Pre-Existing Tax Distortions, Journal of Economics, Vol. 28, No. 4, pp. 708-731.

Goulder, L., Parry, I., Williams, R., and Burtraw, D., 1999. The Cost-Effectiveness of Alternative Instruments for Environmental Protection in a Second-Best Setting, Journal of Public Economics, Vol. 72, No. 3, pp. 329-360.

Grainger, C., and Kolstad, C., 2010. Who Pays a Price on Carbon? Environmental and Resource Economics, Vol. 46, No. 3, pp. 359-376.

Granade, H., Creyts, J., Derkach, A., Farese, P., Nyquist, S., and Ostrowsly, K., 2009. Unlocking Energy Efficiency in the U.S. Economy. McKinsey Global Energy and Materials.

Intergovernmental Panel on Climate Change, 2006. Revised 1996 IPCC Guidelines for National Greenhouse Gas Inventories: Reference Manual.United Nations Framework Convention on Climate Change.[http://bit.ly/1eIL9lb.]

International Monetary Fund [IMF], 2014.Fiscal Policy to Address Energy's Environmental Impacts.IMF Survey Magazine.[http://bit.ly/1xGOCai.]

Jorgenson, D.,2014.Time to Tax Carbon.Harvard Magazine,Sep.-Oct.,pp. 52-56 and78-79. [http://bit.ly/1dDlxtI.]

Jorgenson, D., Goettle, R., Ho, M., and Wilcoxen, P., 2013.Double Dividend: Environmental Taxes and Fiscal Reform in the United States, MIT Press.

Ligthart, J., 1998. The Macroeconomics Effects of Environmental Taxes: A Closer Look at the Feasibility of Win-Win Outcomes.International Monetary Fund Working Paper98-75.

Klenert, D., and Mattauch, L., 2016. How to Make a Carbon Tax Reform Progressive: The Role of Subsistence Consumption, Economics Letters, Vol. 138, pp. 100-103.

Krupnick, A., Parry, I., Walls, M., Knowles, T., and Hayes, K., 2010. Towards a New National Energy Policy: Assessing the Options. Resources for the Future and National Energy Policy Institute, Washington, DC.

Mankiw, N.G., 2013. A Carbon Tax that America Could Live With.The New York Times.August31 ${ }^{\text {st }}$ [http://nyti.ms/1FguZcm.] 
Metcalf, G., 2010. On the Use of Carbon Fees to Achieve Fiscal Sustainability in the Federal Budget.SelectedWorks. [http://bit.ly/1HZrACO.]

Newell, R., and Siikamaki, J.,2015. Individual Time Preferences and Energy Efficiency, National Bureau of Economic Research Working Paper No. 20969.

Nordhaus, W., 2010.Carbon Taxes to Move Toward Fiscal Sustainability.The Economists'Voice, Vol. 7, No. 3, Article 3. [http://bit.ly/1LUcSxO.]

OECD, 2004. Environment and Employment: An Assessment, Organisation for Economic Cooperation and Development. Paris.

OECD, 2011.Environmental Taxation: A Guide for Policy Makers.Organisation for Economic Cooperation and Development. Paris.

OECD, 2014.Portugal: Deepening Structural Reform to Support Growth and Competitiveness,Better Policies Series.July.Paris. [http://bit.ly/1GLWrnN.]

Parry, I., Heine, D., Lis, E., Shanjun, L.,2014.Getting Energy Prices Right: From Principles to Practice.International Monetary Fund. Washington, DC.

Pereira, A., Pereira, R., 2012. DGEP - A Dynamic General Equilibrium Model of the Portuguese Economy: Model Documentation. The College of William and Mary, Economics Department Working Paper 127 (revised in 2014).

Pereira, A., Pereira, R., 2013. Fossil Fuel Prices and the Economic and Budgetary Challenges of a Small Energy-Importing Economy: The Case of Portugal,Portuguese Economic Journal, Vol.12, No. 3, pp. 181-214.

Pereira, A., Pereira, R., 2014a. Environmental Fiscal Reform and Fiscal Consolidation: The Quest for the Third Dividend in Portugal,Public Finance Review, Vol. 42, No. 2, pp. 222-253.

Pereira, A., Pereira, R., 2014b.On the Environmental, Economic and Budgetary Impacts of FossilFuel Prices: A Dynamic General-Equilibrium Analysis of the Portuguese Case,Energy Economics, Vol. 42, No. C, pp. 248-261.

Pereira, A., Pereira, R.,2014c.ANNEX IV: Technical Report for the DGEP Model Results Prepared for the Commission for Environmental Fiscal Reform.[http://goo.gl/qwPIBL.] 
Pereira, A., Pereira, R., 2014d.The Environmental and Economic Effects of the Environmental Fiscal Reform of 2014 in Portugal.[http://goo.gl/eiG0ZS.]

Pereira, A., Pereira, R., 2015a. Reducing Carbon-Dioxide Emissions in Portugal: The Relative Roles of Fossil-Fuel Prices, Energy Efficiency, and Carbon Taxation.The College of William and Mary, Economics Department Working Paper 154.

Pereira, A., Pereira, R., 2015b. Achieving the Triple Dividend in Portugal: A Dynamic GeneralEquilibrium Evaluation of a Carbon Tax Indexed to Emissions Trading. The College of William and Mary, Economics Department Working Paper 155.

Pereira, A., Rodrigues, P., 2002. On the Impact of a Tax Shock in Portugal.Portuguese Economic Journal, Vol. 1, No. 3, pp. 205-236.

Pereira, A., Rodrigues, P., 2004. Strategies for Fiscal Reform in the Context of the EMU: The Case of Portugal. Review of Development Economics, Vol. 8, No. 1, pp. 143-165.

Pereira, A., Rodrigues, P., 2015. Pension Reform in Portugal: A Dynamic General Equilibrium Analysis. Lambert AcademicPublishing.

Seixas, J., and P. Fortes. 2014. Avaliação do Impacto da Taxa de $\mathrm{CO}_{2}$ no Sistema Energético em Portugal o Modelo TIMES_PT. 'Sobre os Efeitos Ambientais e Económicos de uma Nova Tributação sobre o Carbono em Portugal - Anexo III'. Relatório Técnico apresentado à Comissão de Reforma da Fiscalidade Verde. Lisboa, Portugal.[http://goo.gl/UoH3I1.]

Stern, N.,2007.The Economics of Climate Change: The Stern Review, Cambridge University Press.

World Bank, 2014.State and Trends of Carbon Pricing. Washington, DC. 